\title{
Tullio phenomenon in superior semicircular canal dehiscence syndrome
}

回

\section{Figure Left superior semicircular canal dehiscence}

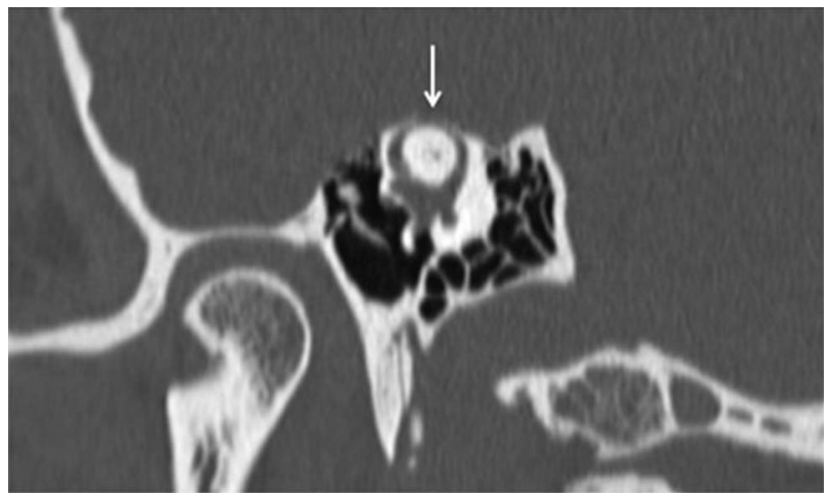

Temporal bone CT reformatted in the Poschl plane shows dehiscent bone over the left superior semicircular canal. Arrow points to the area of dehiscent bone.

Tullio phenomenon refers to eye movements induced by sound. ${ }^{1}$ This unusual examination finding may be seen in superior semicircular canal dehiscence (SSCD) syndrome. ${ }^{2}$ This disorder is due to absent bone over the superior semicircular canal (figure). Patients complain of dizziness triggered by loud sound, aural fullness, autophony, and pulsatile tinnitus. When Tullio phenomenon exists in SSCD syndrome, the patient develops a mixed vertical-torsional nystagmus in which the slow phase rotates up and away from the affected ear (video on the Neurology ${ }^{\circledR}$ Web site at Neurology.org). This pattern of nystagmus aligns in the plane of the dehiscent semicircular canal and is due to excitation of its afferent nerves.

Gregory J. Basura, MD, PhD, Scott J. Cronin, MD, Katherine D. Heidenreich, MD

Supplemental data at Neurology.org
From the Division of Otology-Neurotology, Department of Otolaryngology-Head and Neck Surgery, University of Michigan Health System, Ann Arbor, MI.

Author contributions: Gregory J. Basura, MD, PhD: conception of study, drafting and revising the manuscript. Scott J. Cronin, MD: drafting and revising the manuscript. Katherine D. Heidenreich, MD: conception of study, drafting and revising the manuscript, acquisition of data, and study coordination.

Study funding: No targeted funding reported.

Disclosure: The authors report no disclosures relevant to the manuscript. Go to Neurology.org for full disclosures.

Correspondence to Dr.Heidenreich: kheidenr@med.umich.edu

1. Halmagyi GM, Curthoys IS, Colebatch JG, Aw ST. Vestibular responses to sound. Ann N Y Acad Sci 2005;1039:54-67.

2. Minor LB. Clinical manifestations of superior semicircular canal dehiscence. Laryngoscope 2005;115:1717-1727. 


\title{
Neurology
}

\author{
Tullio phenomenon in superior semicircular canal dehiscence syndrome \\ Gregory J. Basura, Scott J. Cronin and Katherine D. Heidenreich \\ Neurology 2014;82;1010 \\ DOI 10.1212/WNL.0000000000000217
}

This information is current as of March 17, 2014

Updated Information \&
Services
Supplementary Material
References
Subspecialty Collections

Subspecialty Collections

Permissions \& Licensing

Reprints including high resolution figures, can be found at: http://n.neurology.org/content/82/11/1010.full

Supplementary material can be found at: http://n.neurology.org/content/suppl/2014/03/15/82.11.1010.DC1

This article cites 2 articles, 0 of which you can access for free at: http://n.neurology.org/content/82/11/1010.full\#ref-list-1

This article, along with others on similar topics, appears in the following collection(s):

\section{Clinical neurology examination}

http://n.neurology.org/cgi/collection/clinical_neurology_examination Vertigo

http://n.neurology.org/cgi/collection/vertigo

Information about reproducing this article in parts (figures,tables) or in its entirety can be found online at:

http://www.neurology.org/about/about_the_journal\#permissions

Information about ordering reprints can be found online:

http://n.neurology.org/subscribers/advertise

Neurology ${ }^{\circledR}$ is the official journal of the American Academy of Neurology. Published continuously since 1951, it is now a weekly with 48 issues per year. Copyright () 2014 American Academy of Neurology. All rights reserved. Print ISSN: 0028-3878. Online ISSN: 1526-632X.

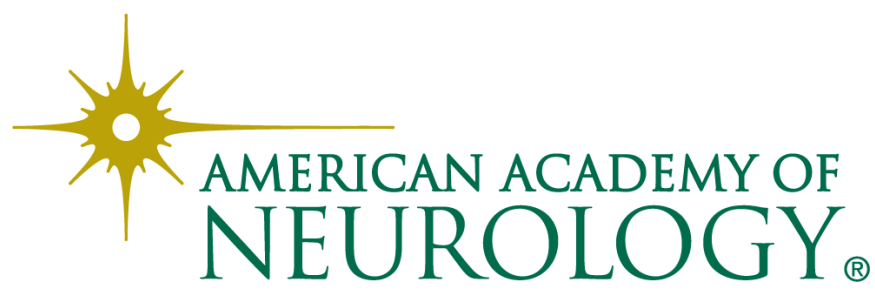

